\title{
A Conceptual Model for Growth and Decay of the Cordilleran Ice Sheet
}

\section{La modélisation du développement et de la régression de l'Inlandsis de la Cordillère}

\section{Ein Begriffsmodell zur Ausdehnung und Abnahme der Kordilleren-Eisdecke}

\author{
Robert J. Fulton
}

Volume 45, numéro 3, 1991

L'Inlandis de la Cordillère

The Cordilleran Ice Sheet

URI : https://id.erudit.org/iderudit/032875ar

DOI : https://doi.org/10.7202/032875ar

Aller au sommaire du numéro

\section{Éditeur(s)}

Les Presses de l'Université de Montréal

\section{ISSN}

0705-7199 (imprimé)

1492-143X (numérique)

Découvrir la revue

Citer cet article

Fulton, R. J. (1991). A Conceptual Model for Growth and Decay of the Cordilleran Ice Sheet. Géographie physique et Quaternaire, 45(3), 281-286. https://doi.org/10.7202/032875ar
Résumé de l'article

La modélisation de l'évolution de l'Inlandsis de la Cordillère a évolué au cours de la centaine d'années de recherches menées en Colombie-Britannique. Si le développement de l'inlandsis a surtout été déterminée par le relief et la localisation par rapport aux vents dominants, le retrait glaciaire a, par contre, principalement été commandé par le relief. Au début de la glaciation, le climat se refroidissant, les glaciers alpins ont progressé pour devenir des glaciers de vallée, qui se sont par la suite fusionnés sur les plateaux pour enfin former un inlandsis. À l'optimum glaciaire, l'inlandsis s'étendait de la marge occidentale du plateau continental jusqu'à la limite des montagnes Rocheuses et du plateau de Columbia jusqu'au centre du Yukon. La partie centrale de l'inlandsis étant entourée de montagnes, il dût y avoir une hausse de la limite des neiges presque jusqu'à l'altitude actuelle avant que le noyau central puisse commencer à fondre. Les glaciers alpins, d'où est issu l'inlandsis, ont ainsi décru presque jusqu'à leurs dimensions actuelles avant qu'il puisse y avoir recul important dans la partie centrale de l'inlandsis. Conséquemment, il y a eu stagnation d'importantes masses de glace, dans la partie intérieure de la Colombie-Britannique, qui ont par la suite été réduites à des lambeaux occupant les vallées principales et, avec le temps, à des blocs de glace inerte recouverts de débris glaciaires. Ce mode de retrait diffère de celui des masses glaciaires occupant les massifs montagneux comme les Alpes où la hausse de la limite des neiges a causé le retrait d'une calotte glaciaire vers son aire d'accumulation originelle, dans le coeur des montagnes.
Tous droits réservés @ Les Presses de l'Université de Montréal, 1991
Ce document est protégé par la loi sur le droit d'auteur. L’utilisation des services d'Érudit (y compris la reproduction) est assujettie à sa politique d'utilisation que vous pouvez consulter en ligne.

https://apropos.erudit.org/fr/usagers/politique-dutilisation/ 


\section{A CONCEPTUAL MODEL FOR GROWTH AND DECAY OF THE CORDILLERAN ICE SHEET*}

Robert J. FULTON, Geological Survey of Canada, 601 Booth Street, Ottawa, Ontario K1A 0E8.

ABSTRACT A conceptual model for growth and decay of the Cordilleran Ice Sheet has evolved over 100 years of Quaternary research in British Columbia. Physiography and location relative to prevailing westerly winds were the main factors controlling the style of glacier build up. The pattern of decay was controlled mainly by physiography. With cooling at the beginning of glaciation, mountain glaciers expanded to become valley glaciers and eventually coalesced on adjacent plateaus or shelves to form an ice sheet. At glacial maximum, this sheet extended from the western margin of the continental shelf to the eastern edge of the Rocky Mountains and from the Columbia Plateau to the central Yukon. The central (highest) part of the ice sheet was hemmed in by mountains, consequently, snowline had to rise nearly to its present elevation before shrinking of the central core could begin. This meant that mountain glaciers which initiated growth of the ice sheet were reduced to near their present dimensions before significant recession could take place in the core area of the ice sheet. As a consequence, large ice masses in the interior of British Columbia stagnated and then shrank to remnants occupying major valleys and eventually were reduced to dead ice blocks buried in glacial debris. This pattern of retreat contrasts with that of ice masses centred on mountain blocks, such as the Alps, where rising of the snowline resulted in recession of ice cap margins back towards original accumulation areas in the central core of the mountains.
RÉSUMÉ La modélisation du développement et de la régression de l'Inlandsis de la Cordillère. La modélisation de l'évolution de I'Inlandsis de la Cordillère a évolué au cours de la centaine d'années de recherches menées en Colombie-Britannique. Si le développement de l'inlandsis a surtout été déterminée par le relief et la localisation par rapport aux vents dominants, le retrait glaciaire $a$, par contre, principalement été commandé par le relief. Au début de la glaciation, le climat se refroidissant, les glaciers alpins ont progressé pour devenir des glaciers de vallée, qui se sont par la suite fusionnés sur les plateaux pour enfin former un inlandsis. À l'optimum glaciaire, l'inlandsis s'étendait de la marge occidentale du plateau continental jusqu'à la limite des montagnes Rocheuses et du plateau de Columbia jusqu'au centre du Yukon. La partie centrale de l'inlandsis étant entourée de montagnes, il dût y avoir une hausse de la limite des neiges presque jusqu'à l'altitude actuelle avant que le noyau central puisse commencer à fondre. Les glaciers alpins, d'où est issu l'inlandsis, ont ainsi décru presque jusqu'à leurs dimensions actuelles avant qu'il puisse y avoir recul important dans la partie centrale de l'inlandsis. Conséquemment, il y a eu stagnation d'importantes masses de glace, dans la partie intérieure de la ColombieBritannique, qui ont par la suite été réduites à des lambeaux occupant les vallées principales et, avec le temps, à des blocs de glace inerte recouverts de débris glaciaires. Ce mode de retrait diffère de celui des masses glaciaires occupant les massifs montagneux comme les Alpes où la hausse de la limite des neiges a causé le retrait d'une calotte glaciaire vers son aire d'accumulation originelle, dans le cœur des montagnes.
ZUSAMMENFASSUNG Ein Begriffsmodell zur Ausdehnung und Abnahme der Kordilleren-Eisdecke. Ein Begriffsmodell zur Ausdehnung und Abnahme der KordillerenEisdecke ist in über 100 Jahren QuaternärForschung in British Columbia ausgearbeitet worden. Für die Art des Gletscheraufbaus waren die Hauptfaktoren das Relief und die Lage in Bezug auf die vorherrschenden westlichen Winde. Der Eisrückzug wurde hingegen vor allem durch das Relief gesteuert. Mit der Abkühlung bei Beginn der Vereisung dehnten sich die Berggletscher aus, wurden Talgletscher und schmolzen schließlich auf angrenzenden Plateaus oder Terrassen zu einer Eisdecke zusammen. Zur Zeit des glazialen Maximums erstreckte sich diese Eisdecke vom westlichen Rand des kontinentalen Plateaus bis zum östlichen Rand der Rocky Mountains und vom Columbia Plateau bis in das Zentrum von Yukon. Der zentrale (höchste) Teil der Eisdecke war durch Berge eingeschlossen, und so mußte die Schneegrenze sich fast bis zu ihrer gegenwärtigen Höhe anheben, bevor das Schmelzen des zentralen Kerns beginnen konnte. Das bedeutet, daß die Berggletscher, welche die Zunahme der Eisdecke einleiteten, fast bis auf inre gegenwärtige Größe reduziert wurden, bevor es im Kerngebiet der Eisdecke zu einem bedeutenden Rückzug kam. Folglich kam es zu einer Stagnation breiter Eismassen im Innern von British Columbia, die dann zu Resten in den Haupttälern schrumpften und schließlich zu toten Eisblöcken, die mit glazialem Schutt bedeckt waren, reduziert wurden. Dieses Rückzugsmuster kontrastiert mit dem der Eismassen auf Bergmassiven wie den Alpen, wo die Anhebung der Schneegrenze zu einem Rückzug der Eiskappe-Grenzen auf ihre ursprünglichen Akkumulationsgebiete im zentralen Kern der Berge führte.

* Geological Survey of Canada Contribution No. 43290

Manuscrit reçu le 25 novembre 1990; manuscrit révisé accepté le 20 septembre 1991 


\section{INTRODUCTION}

The Cordilleran Ice Sheet is the complex of glaciers which formed a more or less continuous body of ice in the western Cordillera of North America during each of the late Cenozoic glaciations. It might be assumed that since this is an area of mountains that the ice sheet acted like a mountain ice cap with inception occurring in high mountains, glaciers advancing down mountain valleys, and the retreat pattern being a mirror image of the advance. More than 100 years of observation (Jackson and Clague, 1991), however, has shown a different pattern of retreat. The objective of this paper is to present the general concepts that have been developed and used to explain the general pattern of growth and decay of the Cordilleran Ice Sheet.

\section{PHYSIOGRAPHIC AND METEOROLOGICAL SETTING}

The mountains in which the Cordilleran Ice Sheet developed lie on the western side of Canada. The Canadian Cordillera consists of three general belts, referred to as the Eastern, Central and Western systems (Bostock, 1948, Fig. 1). The total width of these three belts is about $900 \mathrm{~km}$. The eastern and western belts are mainly north-south trending mountains, reaching elevations of from 2400 to $3300 \mathrm{~m}$. Highest peaks are generally cut by cirques, with alpine glaciers and ice fields common in many higher parts of the mountain ranges today. These mountainous belts tend to form walls on either side of the lower central belt which mainly consists of broad plateaus and rolling uplands that are separated and locally dissected by broad, deep valleys. Elevations in the central belt range from 900 to $2100 \mathrm{~m}$ (Fig. 1).

The Canadian Cordillera lies in the belt of prevailing westerly winds (Hare and Hay, 1974). Consequently, most of its precipitation comes from the Pacific Ocean and in general western sides of mountain ranges are wet with lower precipitation on eastern sides (see Fig. 9.14 of Day, 1989). This is an important factor in controlling the nourishment of glaciers. Because of this pattern of precipitation, the main modern glaciers are in the Coast Mountains; glaciers and local ice fields are present in the mountains further east but are of minor extent compared to those of the Coast Mountains.

\section{INCEPTION AND GROWTH OF THE CORDILLERAN ICE SHEET}

The picture of inception and growth of the Cordilleran Ice Sheet that is outlined below is highly speculative because almost no evidence remains of this early phase of glaciations. The concepts which are presented are based largely on a consideration of glacial principles and on evidence remaining from the climax of the last glaciation. A good conceptualization of Cordilleran Ice Sheet growth was presented by Davis and Mathews (1944, Fig. 2). During their first phase of glaciation, relief greatly exceeded ice thickness, glaciers were restricted to high mountain areas, and ice flow was completely controlled by topography (Fig. 2a). In their second phase, glaciation had progressed to the point where much of the area was ice covered but relief slightly exceeded ice thickness (Fig. 2b). At this

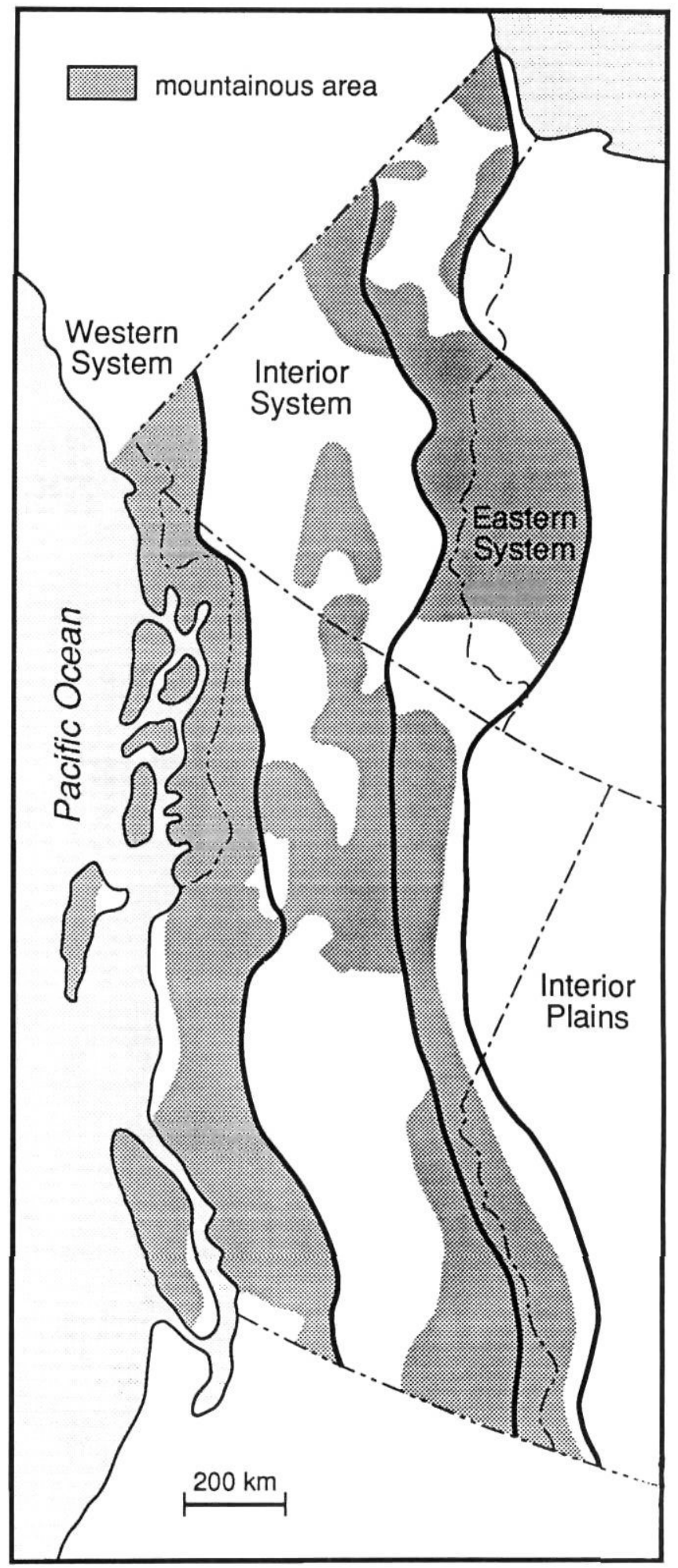

FIGURE 1. Location map

Carte de localisation 


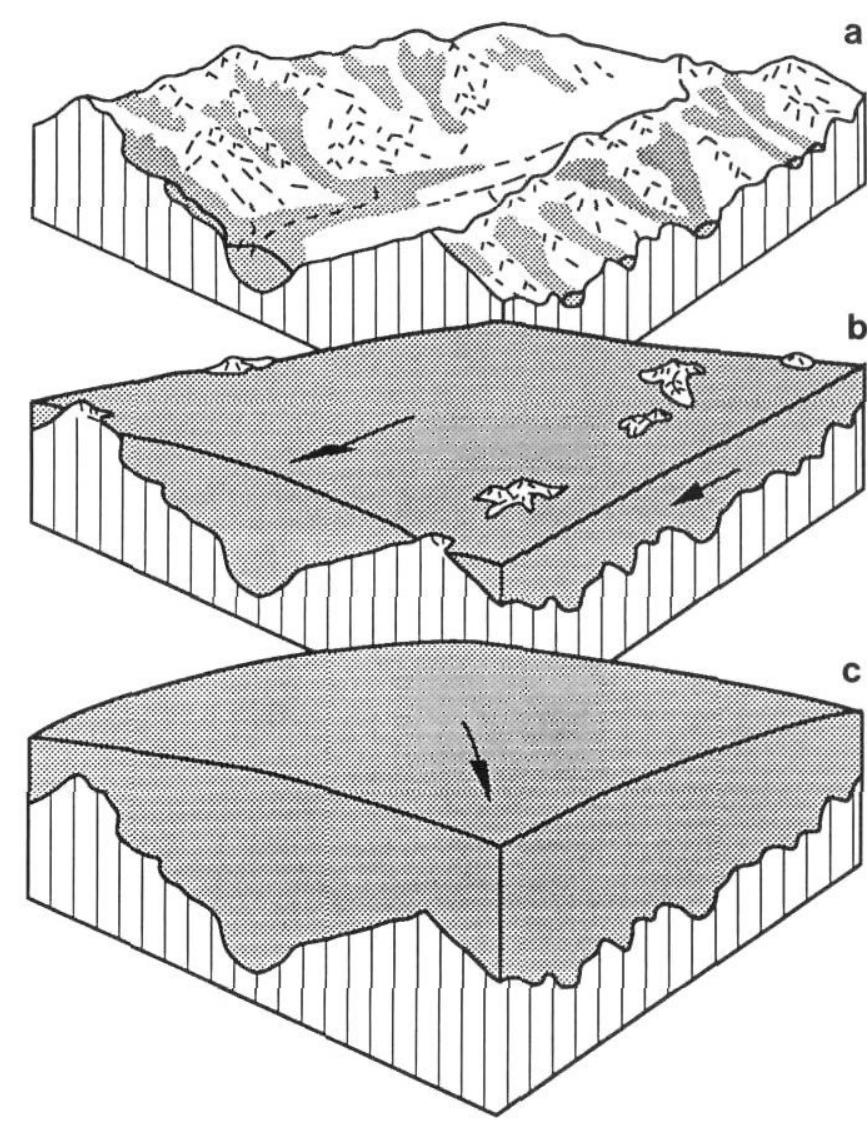

FIGURE 2. Davis and Mathews phases of glaciation (after Davis and Mathews, 1944): a) ice thickness much less than relief, glacier flow controlled by topography; b) ice thickness approximately equal to relief so all except highest peaks are covered, glacier flow still is largely controlled by topogaphy; c) ice thickness much greater than relief, ice flow largely controlled by regional ice sheet gradient.

Les phases de la glaciation d'après Davis et Mathews (1944). a) Relief dominant par rapport à la glace; écoulement glaciaire commandée par le relief, b) Recouvrement presque total par la glace, sauf pour quelques pics; écoulement glaciaire encore surtout déterminée par le relief, c) Relief entièrement recouvert par une très grande épaisseur de glace; écoulement glaciaire surtout commandé par le gradient régional de l'inlandsis.

stage topography continued to control glacier movement with most flow taking place in the large valleys which separate nunataks. In their third phase (not shown in Fig. 2), ice thickness exceeded relief but because topography below the ice was rugged, flow tended to move parallel to major topographic elements. During the final, or full ice sheet phase, ice thickness greatly exceeded relief and movement of the glacier was controlled by the location of main accumulation and ablation areas (Fig. 2c). At this stage topography no longer controlled glacier flow and the ice could move independent of the major topographic elements. This model was an extension of ideas developed by Kerr (1934) and was in part based on the work of Dawson (1891) and observations of other early workers. The patterns of ice flow associated with different levels of glaciation, as illustrated in various regional compilations since the Davis and Mathews (1944) publication have largely substantiated

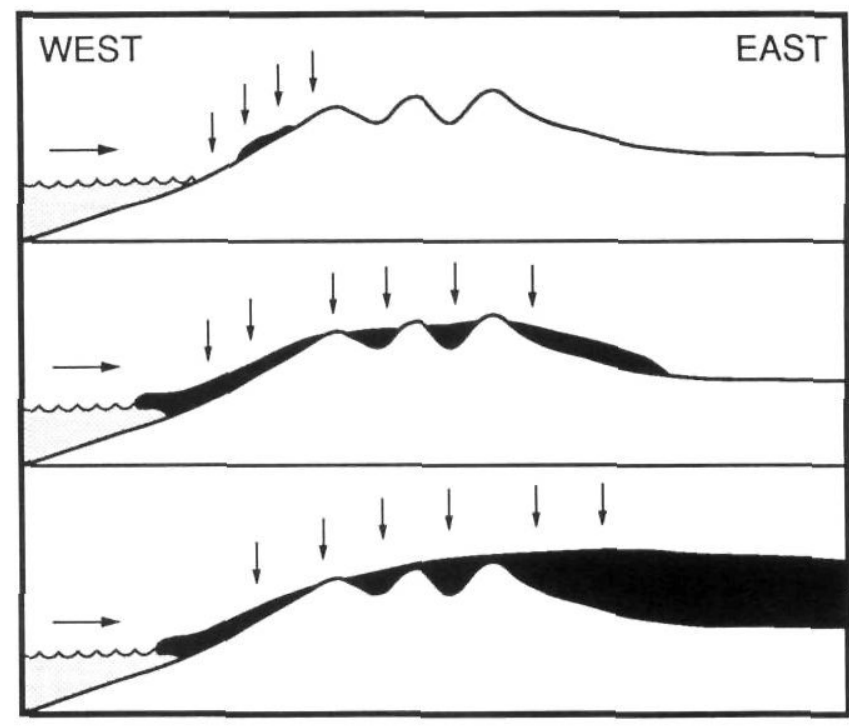

FIGURE 3. Flint (1957) model for Scandinavian Ice Sheet inception. Le modele de Flint (1957) illustre la naissance de l'Inlandsis scandinave.

their conclusions (Glacial Map of Canada, 1958; Mathews, 1955; Tipper, 1971; Clague, 1989).

A second model to consider when looking at inception of mountain ice sheets is the one proposed for the Scandinavian Ice Sheet (Flint, 1957, Fig. 3). The Scandinavian situation is similar to that of the Canadian Cordillera in that both areas lie in belts of prevailing onshore winds and both have coastal mountain ranges. According to Flint (1957), inception of glaciation in this area began with the growth of alpine glaciers. With lowering of snowline the glaciers expanded to the east and west. Most accumulation occurred on the western or ocean side of the mountains but calving into the ocean limited build up in this area. Glaciers flowing eastward from the mountains, on the other hand, developed into piedmont lobes which eventually coalesced and became a fully developed ice sheet with its own accumulation area east of the crest of the mountains. The general principles of this model have been largely substantiated by recent work. It has however, been shown that the ice divide never shifted far east of the crest of the mountain ranges, particularly in the southern part of the area (Nesje et al., 1988).

The ideas on development of the Scandinavian lce Sheet from alpine glaciers put forward by Flint (1957) closely follow the model presented by Davis and Mathews (1944). The two areas differ however, in that an extensive plateau and plain area lies east of the Scandinavian coastal mountains whereas, the area inboard from the coastal mountains of the Canadian Cordillera consists of lower elevation plateaus bounded by mountains. In the Scandinavian situation, the coalesceing glaciers were relatively free to move away from the alpine glacier sources. In the Cordilleran situation, ice was trapped in the interior and in addition, glaciers pushed into the interior from all sides.

In the conceptual picture developed for inception in the Canadian Cordillera, alpine glaciers grew to become alpine ice 
caps (Fig. 4a and b). Piedmont lobes next developed and these coalesced along the mountain fronts (Fig. 4c). Eventually, the coalesced piedmont lobes developed into an ice sheet with its accumulation area centred over the interior of the Cordillera (Fig. 4d). At this stage the ice in the interior took on a life of its own and instead of the interior acting as a sink for ice from the surrounding mountains, the ice from the interior pushed back into and in some places overtopped Eastern and Western System mountains.

The concepts of inception and growth of the ice sheet are relatively simple but the actual processes would have been very complex. During inception, climatic factors would have varied as regional factors such as zonal air flow changed. The pattern of air flow and precipitation would also have varied as development of glaciers and ice caps, the accompanying isostatic downwarping, and changes in sea level effected local conditions. These changes would have resulted in shifting dominance of accumulation areas and changing patterns of ice flow. Because there were so many degrees of freedom in the initiation pattern, it is unlikely that the pattern of ice movement was the same for any two glaciations.

Development of a single ice dome centred in the Interior System is the climax situation for a Cordilleran Ice Sheet. Fulton (1967), using data presented by the Glacial Map of Canada (1958), inferred that this climax stage was reached during the

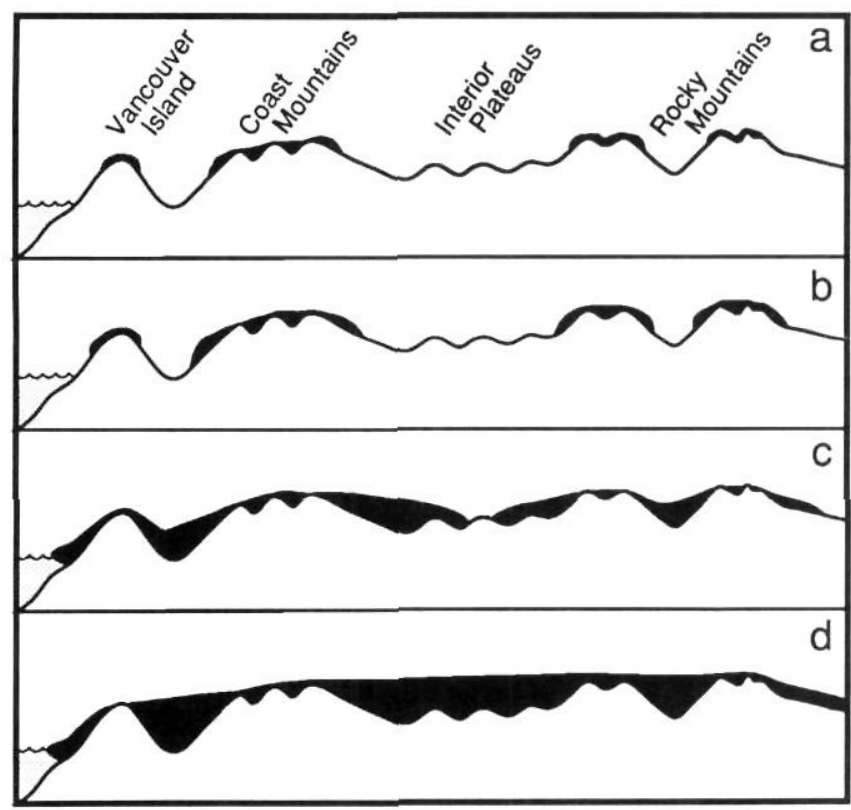

FIGURE 4. Concept of Cordilleran Ice Sheet inception and growth: a) development of alpine glaciers; b) alpine glaciers grow into mountain ice caps; c) piedmont lobes develop adjacent to main mountain chains and begin to coalesce; d) at the climax stage the coalesced ice mass becomes an ice sheet.

Conception de la naissance et du développement de l'Inlandsis de la Cordillère: a) développement de glaciers alpins; b) transformation des glaciers alpins en calottes alpines; c) développement de lobes de piémont adjacents aux chaînes de montagnes et début de coalescence; d) développement d'un inlandsis à partir des masses de glace fusionnées, à l'optimum glaciaire. last glaciation with the central dome of the ice sheet located in the vicinity of the 52nd parallel. It is however, unlikely that ice accumulation was such that a single dome or ridge developed in the Interior System during any glaciations; in most instances the Cordilleran Ice Sheet probably never grew beyond being the series of mountain ice caps and ice domes separated by saddles that apparently existed during the last glaciation (Fig. 5; Tipper, 1971; Clague, 1989).

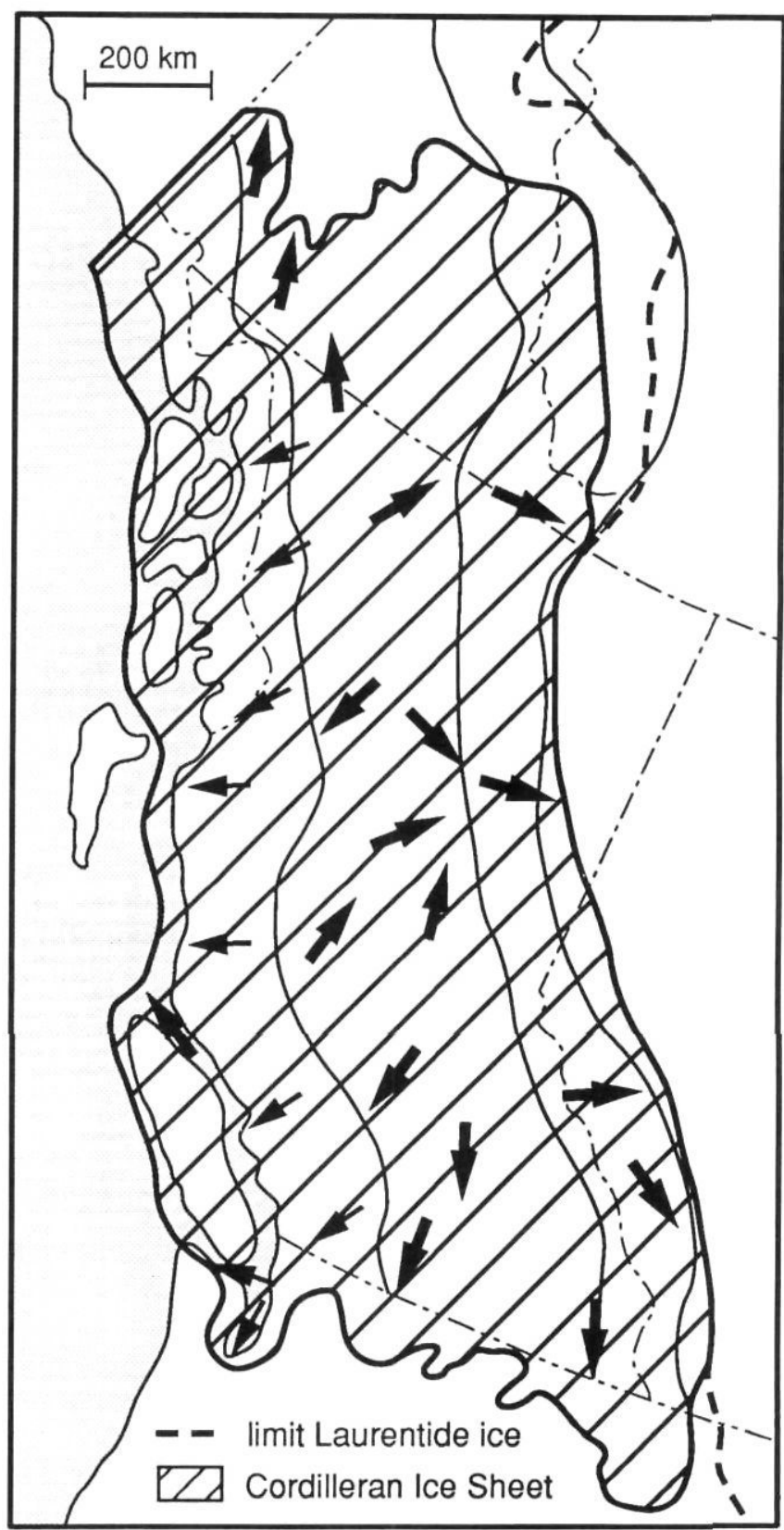

FIGURE 5. General flow pattern of Cordilleran Ice Sheet at climax of last glaciation (after Clague, 1989).

L'allure générale de l'écoulement glaciaire de l'Inlandsis de la Cordillère à l'optimum de la dernière glaciation. 


\section{DEGLACIATION}

The inception and buildup story are relatively speculative but there is considerable information that permits development of a comparatively complete picture of deglaciation of the Cordilleran Ice Sheet. This evidence consists mainly of features which indicate direction of ice flow during later stages of glaciation and features related to meltwater flow and deglaciation which indicate the style, and pattern of ice retreat.

During recession of alpine ice caps the ice front retreats up mountain valleys towards initial accumulation areas (Fig. 6). In the southern interior of British Columbia however, there is little evidence that during retreat of the Cordilleran Ice Sheet ice tongues receded into the mountains. Instead, all evidence points towards breakup of the ice sheet into several remnant masses with ice margin retreat towards the central parts of these masses which in general were stranded in lower parts of the Interior System.

Why did the glaciers not retreat back towards mountain accumulation areas as might have been expected? There are two apparent reasons: First, the ice in the interior was topographically confined by mountains so that the equilibrium line had to rise above the level of most alpine accumulation areas before significant downwasting could occur in the interior and second, the thickest part of the ice sheet was located in lower parts of the interior and not at the sites of initial accumulation in the mountains.

When glaciation had reached the stage where ice domes were active in the interior of the Canadian Cordillera, ice flow was directed from these local centres towards the adjacent mountains. For this to occur the domes had to be higher than the elevation of the surrounding mountains (Fig. 7a). Before significant down wasting of the ice sheet could begin, a large part of the ice sheet area had to lie below the equilibrium line. Given the topographic configuration of the area and the confinement of the central parts of the ice sheet, snowline would have had to rise above the elevation of most of the main initial accumulation areas in the mountains before this could

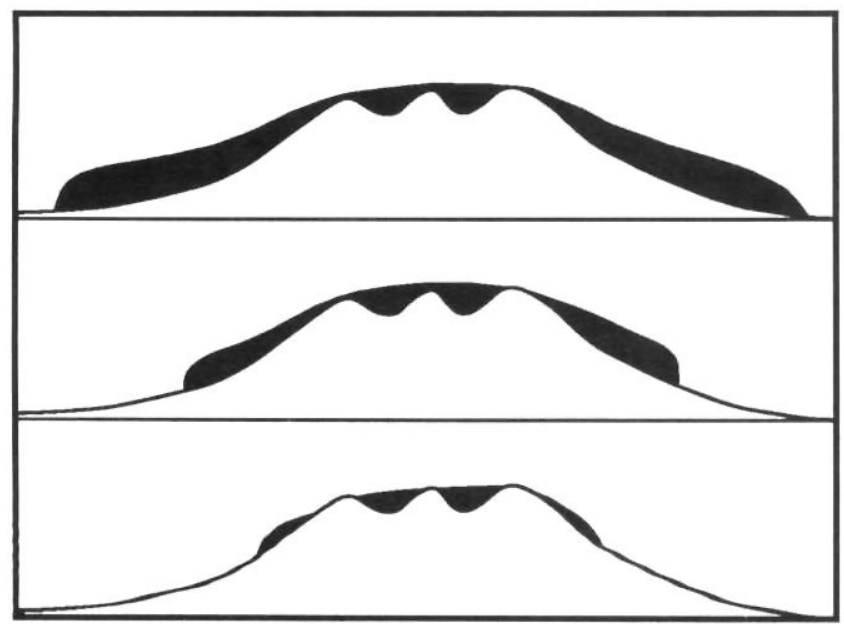

FIGURE 6. Conceptual model for retreat of an alpine ice cap.

Modèle conceptuel du retrait d'une calotte glaciaire alpine. be achieved. Consequently, the initial accumulation areas were not major sources of ice during retreat of the Cordilleran Ice Sheet. Major consequences of this pattern of retreat are that an extended period of alpine glaciation did not occur at the end of glaciation and alpine ice was no more active during recession of the Cordilleran Ice Sheet than it is today.

Once the equilibrium line had been elevated to the level of the alpine accumulation areas, the ice sheet would have largely stagnated. The thickest part of the ice sheet was located in the relatively low interior of the Cordillera and not at the initial accumulation areas in the mountains. This meant that the greatest volume of ice lay in the interior and as a consequence, during stagnation, the ice would have shrunk towards the areas of relatively thick ice in the interior.

The ultimate results of topographic confinement and thicker ice in the interior are that retreat of the Cordilleran Ice Sheet did not mirror advance (during breakup the ice margin retreated from mountain areas towards the interior) and the last remnants of the Cordilleran Ice Sheet lay in relatively low lying areas rather than in the adjacent mountains.

This pattern of retreat differs from that of the Scandinavian Ice Sheet which had a similar pattern of inception but was not topographically confined. In the case of the Scandinavian Ice Sheet, the main accumulation zone tended to migrate back towards alpine areas during recession and instead of stagnating and dissipating largely in place, several recessional moraines were constructed (Lundqvist, 1986).

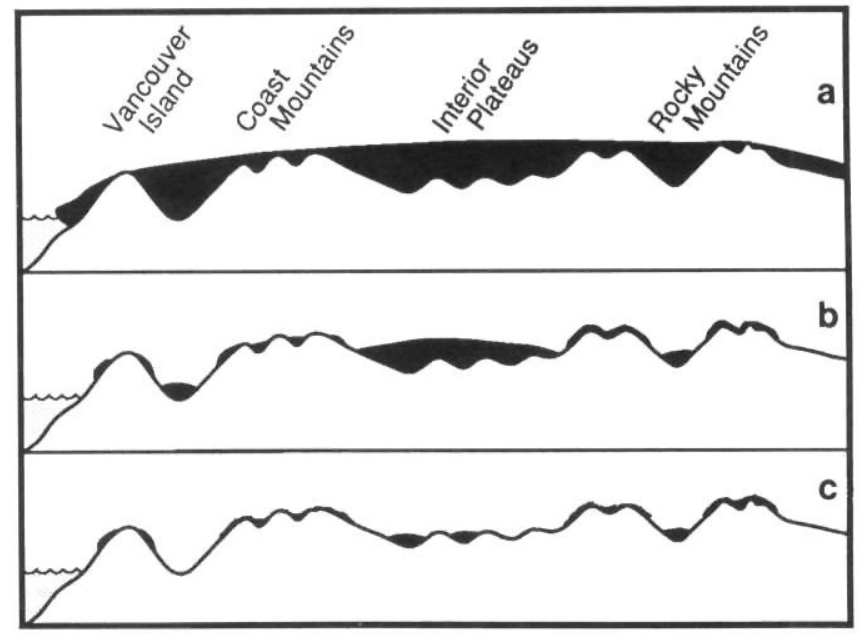

FIGURE 7. Conceptual picture of retreat of the Cordilleran Ice Sheet: a) climax Cordilleran Ice Sheet with a dome centred in the interior of the Cordillera; b) with the equilibrium line elevated to near the tops of the mountains, deglaciation of the mountains begins while large ice masses remain in lower areas; $c$ ) alpine glaciers remain in high areas (as they do today) and Cordilleran lce Sheet is redeced to scattered stagnant ice masses in the interior of the Cordillera and in the main valleys.

Modèle conceptuel du retrait de l'Inlandsis de la Cordillère: a) étendue maximale de l'Inlandsis de la Cordillère dont le dôme est centré sur l'intérieur de la Cordillère; b) la ligne d'équilibre étant située près du sommet des montagnes, la déglaciation des montagnes commence pendant que les masses de glace occupent encore les parties basses; c) les glaciers alpins occupent les parties hautes (comme aujourd'hui) et l'Inlandsis est réduit à des lambeaux de glace disséminés à l'intérieur de la Cordillere et dans les principales vallées. 


\section{CONCLUSIONS}

Three main conclusions can be drawn from this conceptual model of the Cordilleran Ice Sheet.

1) Physiography and prevailing onshore winds were the primary controls on inception and growth, and physiography played a major role in controlling the style of deglaciation of the Cordilleran Ice Sheet.

2) Inception began in the mountains with alpine glaciers growing into piedmont lobes which coalesced and eventually became an ice sheet which was largely confined to the interior of the Canadian Cordillera by surrounding mountains.

3) Retreat began in the mountains, proceeded towards lower relief areas, and ended with large scale stagnation in the interior.

\section{ACKNOWLEDGEMENTS}

This manuscript benefitted greatly from the critical review of John Fyles, Brent Ward and an anonymous reviewer. Tracy Barry of Terrain Sciences Division drafted the diagrams.

\section{REFERENCES}

Bostock, H. S., 1948. Physiography of the Canadian Cordillera, with special reference to the area north of the fifty-fith parallel. Geological Survey of Canada, Memoir 247. $106 \mathrm{p}$.

Clague, J. J., 1989. Cordilleran Ice Sheet, p. 40-42. In R. J. Fulton, ed., Quaternary Geology of Canada and Greenland. Geological Survey of Canada, Geology of Canada, No. 1, 839 p. (also Geological Society of America, The Geology of North America, Vol. K-1).

Davis, N. F. G. and Mathews, W. H., 1944. Four phases of glaciation with illustrations from southwestern British Columbia. Journal of Geology, 52: 403-413.
Day, T. J., 1989. River processes, p. 595-604. In R. J. Fulton, ed., Quaternary Geology of Canada and Greenland. Geological Survey of Canada, Geology of Canada, No. 1, 839 p. (also Geological Society of America, The Geology of North America, Vol. K-1).

Dawson, G. M., 1891. On the later physiographical geology of the Rocky Mountain region in Canada, with special reference to changes in elevation and to the history of the glacial period. Royal Society of Canada, Transactions, 8(4): 3-74.

Flint, R. F., 1957. Glacial and Pleistocene Geology. Chapman and Hall, London, $553 \mathrm{p}$.

Fulton, R. J., 1967. Deglaciation studies in Kamloops region, an area of moderate relief, British Columbia. Geological Survey of Canada, Bulletin 154, $36 \mathrm{p}$.

Glacial Map of Canada, 1958. Glacial Map of Canada. Geological Association of Canada, Toronto.

Hare, F. K. and Hay, J. E., 1974. The Climate of Canada and Alaska, p. 49-192. In R. A. Bryson and F. K. Hare, ed., The Climate of Canada and Alaska. Elsevier, Amsterdam.

Jackson, L. E. and Clague J. J., 1991. The Cordilleran Ice Sheet: one hundred years of exploration and discovery. Géographie physique et Quaternaire, 45(3): $269-280$

Kerr, F. A., 1934. Glaciation in northern British Columbia. Royal Society of Canada, Transactions, Ser. 3, 28(4): 17-31.

Mathews, W. H., 1955. Late Pleistocene divide of the Cordilleran Ice Sheet (abstract). Geological Society of America, Bulletin, 66: 1657.

Nesje, Atle, A., Dahl, S. O. and Rye, N., 1988. Block fields in southern Norway. Significance for the Late Weichselian ice sheet. Nors Geologisk Tidsskrift, 68: 149-169.

Lundqvist, J., 1986. Late Weichselian glaciation and deglaciation in Scandinavia. In V. Sibrava, D. Q. Bowen and G. M. Richmond, ed., Quaternary Glaciations in the Northern Hemisphere. Quaternary Science Reviews, 5: 269-292.

Tipper, H. W., 1971. Multiple glaciation in central British Columbia. Canadian Journal of Earth Sciences, 8: 743-752. 